\title{
Autonomy versus Authority: Approaches to Canadian Municipal Reform
}

\author{
Melissa Oldreive
}

Since Confederation in 1867, Canada has become a highly urbanized nation. In fact, just over half a century later, Canada was classified as an urban nation (Tindal and Tindal, 2009, 65). Since the early part of the twentieth century, Canada has continued to become increasingly urbanized. This has had, and will continue to have, profound implications on how government is structured and how it represents its citizens. This paper argues that governments must address the interests of urban populations and governments in cooperative forums as opposed to strictly formal institutional means. Beginning with the importance of municipalities in the Canadian context, this paper will outline why the municipal question, regarding what level of autonomy municipalities and local governments should be granted, cannot be ignored. This paper will then go on to explain the different historical approaches to municipal reform at the federal level as a reaction to the increasing urbanization of Canadian society. Giving weight to both municipal autonomy and municipal authority arguments, this paper will express the importance of addressing municipal concerns, and that the best way to go about doing so is through pragmatic cooperation.

The importance of municipalities cannot be underestimated in the Canadian context. In 2006, 68\% of Canadians lived in Canada's 33 census metropolitan areas (known as CMAs) (Statistics Canada, 2009-01-20) with 80\% (a little more than 25 million people) living in urban areas. ${ }^{1}$ Further, the "big three" (Toronto, Vancouver,

\footnotetext{
${ }^{1}$ Note the distinction between CMAs and urban areas: CMAs are defined as areas that "have at least 100 000 population, including an urban core with at least 50000 people" while urban areas are labeled as
} 
Montreal) are the most populous areas in the nation: "The Montreal and Vancouver CMAs and the Greater Golden Horseshoe (GGH) in Ontario now contain almost half the population of the country" (Tindal and Tindal, 2009, 65). With nearly all of the electorate living in urban areas, upper levels of government must recognize the importance of local governments. Similarly, this population density requires effective and efficient governments at the local level. As such, Canadian governmental policy is heavily affected by the settlement patterns of the nation: Where people live has, or should have, a large impact on policy making.

The distribution of the Canadian population also has profound implications on the country's governance. Because most Canadians live within "a belt reaching only about 150 miles north of the border" with America (Martin, 1990, 50), Canada is a nation influenced by its dominating neighbour to the south. As indicated in the title of his book, The Limits of Boundaries, Andrew Sancton argues that the effects of a large municipality reach beyond its own borders: Often times, people living in smaller, adjacent municipalities benefit from the economic strength of a larger municipality because, he argues, boundaries are artificial $(2008,133){ }^{2}$ Similarly, the border between Canada and America does not block the effects of economics. In fact, this economic interaction between the two countries has led to their economic integration (Grinspun and Shamsie, 2007). Further, "North American integration has played a central role in defining the direction of [Canadian] public policy" (Grinspun and Shamsie, 2007, 4). Because of the majority of the population's closeness to the United States, Canadian integration with the American economy is not only inevitable, but is also influential in matters of governance.

As alluded to above, city regions are extremely important to the Canadian economy. In fact, in all countries, city regions serve as drivers of national economies as "[g]lobalization has had a positive impact in making cities and city regions increasingly important as key players in the world economy" (Tindal and Tindal, 2009, 197). In the Canadian context, in 2006, the Toronto CMA contributed to 49\% of Ontario's Gross Domestic Product; Winnipeg 65\% to its province's GDP; and the Montréal Region

"places with a population of 1000 or more, with a population density of at least 400 people per square kilometere" (Tindal and Tindal, 2009, 64-65).

2 These communities have been defined as "free-riders" and "edge cities" (Tindal and Tindal, 2009, 66). 
contributed a total of 51\% (Tindal and Tindal, 2009, 65). ${ }^{3}$ Because of their economic importance, influence, and spread, municipalities cannot be ignored in the Canadian context.

This is not to say, however, that municipalities are consulted in intergovernmental negotiations and agreements. In fact, they are quite often ignored as local governments are bound to legislation and agreements agreed upon by upper level of governments, and, as such, must adhere to international agreements that do not always benefit them. Such agreements include the North American Free Trade Agreement (NAFTA) and the Canada-US Free Trade Agreement (CUFTA). ${ }^{4}$ While municipalities are drivers of the economy, it must be realized that they are "also affected, directly and indirectly, by the globalization of the economy and the international organizations and agreements related to that process" (Tindal and Tindal, 2009, 194-195). The fact that municipal governments are not required participants in international agreements clearly demonstrates the constitutional, or lack thereof, nature of local governments. As "creatures of provinces" (enshrined in Section 92(8) of the Canadian Constitution), local levels of government have no authority to make international agreements, and, as such, are subject to the agreements made on their behalf by their respective provincial governments.

This lack of control and power has sparked many municipal autonomy movements, particularly in Canada's CMAs (largely in Toronto). Seeking a level of autonomy similar to the Québécois anthem, "maitre chez nous" (masters of our own house), ${ }^{5}$ advocates for municipal autonomy call for radical constitutional change in order to create city-states. Urban autonomists seek equality with other "orders" (as opposed to "levels") of governments because, as mentioned above, urban centres are drivers of national and provincial economies, and also because they view the way local governments are subjected to provincial will as an undemocratic process. The way to address these deficits in representation and democracy, autonomy advocates argue, is through creating individual city-states out of Canada's largest CMAs (Toronto, Montréal, Vancouver) that are equal in autonomy to their provincial counterparts. Autonomy

\footnotetext{
${ }^{3}$ The original source of this data comes from Federation of Canadian Municipalities, Our Cities, Our Future, Big City Mayors' Caucus, June 2006, p. 21.

${ }^{4}$ Tindal and Tindal, as well as Grinspun and Shamsie discuss this throughout their texts.

5 This metaphor is discussed in Alan Broadbent's Urban Nation, 2008, pg 2-3.
} 
advocate Alan Broadbent, in his treatise Urban Nation, argues that the need for urban autonomy is focused on the true Canadian reality: The "economic nature of the country has changed dramatically" from rural resource extraction to urban concerns such as production and manufacturing (2008, 16-17), and as a result, populations have moved from rural to urban areas (15). This proves problematic as the distribution of the seats in the House of Commons still shows "a strong bias towards rural representation" (Broadbent, 2008, 14) as based on older population patterns. This leaves city-regions extremely under-represented in the parliamentary system, and as a result, leads persons like Broadbent to call for constitutional change, via urban autonomy, to correct this problem.

In contrast to those who view municipal authority as limited and rigid, often referred to as Dillon's Rule where municipal authority is only what is granted by a province, there are those who view municipal control as being over "anything that is not explicitly prohibited by state (or provincial) legislation" (Tindal and Tindal, 2004, 196). This is referred to as "Home Rule." Advocates for this approach to municipal control acknowledge the importance of the urbanization of Canada, but unlike municipal autonomists, they seek to work within constitutional constraints and remain creatures of provinces. As such, local governments are forced to find ways to govern creatively within their own areas of jurisdiction. In the case of NAFTA, some advocates note that despite "policy constraints imposed by free trade [...] local governments in Canada still control many policy levers that can be used to reverse [the negative results]" of free trade (Grinspun and Shamsie, 2007, 6). This view acknowledges the near impenetrability of the Canadian Constitution, and seeks to worth within its frameworks as opposed to fighting them.

In this way, the latter view is neither explicitly Home nor Dillon's Rule, but a compromise of the two, referred to as the "Mushy Middle." Known as the space where personality matters, the Mushy Middle seeks a compromise between the rule of law and the realities of local government; Andrew Sancton points out that such "cooperative arrangements among municipalities within cities are obviously desirable and necessary" to effective local governance $(2008,5)$. These are pragmatic notions centered on the idea 
of cooperation in contrast to municipal autonomy that seeks radical municipal change. Sancton points to another pragmatic concern: "Canadians are searching for cheaper, more efficient government as a means of improving their overall economic situation," and it is therefore "not surprising that some are advocating [for] fewer governments" $(1994,97)$, in contrast to the preference of city-state advocates.

These two views, autonomy and authority, are two different approaches to municipal reform in light of Canada's increased urbanization since Confederation. Since 1867, Canada's city-regions have not only increased in number, but also in their individual population. Statistics Canada shows that Canada went from being 19\% urban in 1871 to $80 \%$ urban in 2006 (2009-09-02). As a result, cities are no longer acting just as geographic settlements, but are now acting as political expressions of people within their territory (via local governments), and, in addition to their economic importance, are becoming increasingly important in the Canadian political system.

As discussed above, political reactions to this increased urbanization have been varied. Perhaps the first true political acknowledgement of Canada's urbanization was in Prime Minister Pierre Elliot Trudeau's creation of the Ministry of State for Urban Affairs (MSUA) in 1971. MSUA's goal was horizontal in nature as is sought to integrate urban issues across governmental departments rather than to provide direct services to cities. While being a formal institution of government, MSUA also initiated the beginning of trilevel relationships between federal, provincial, and municipal governments, allowing for cooperation and informal governance. The ministry was abolished not long after as the decade marked a shift towards regionalism and away from a concern over urban affairs. This ended the first phase of the federal-municipal relationship.

That is not to say that regionalism took over the federal agenda. In the period of the Meech Lake and Charlottetown Accords (1987-1992), discussion on the constitutionality of the Canadian Constitution abounded, leading many to discuss the possible changes that could be made to Section 92(8), and how local governments could gain more authority and/or autonomy. With the failure of the Accords, discussion of more constitutional change was halted as Canadians began to suffer from 'constitutional fatigue' (Robinson and Simeon, 2004, 119). As such, municipal hope for a changed 
relationship rested with individual provinces. Even urban autonomists have come to realize that the "mechanism [of Constitutional change has been locked] away for a generation or more" (Broadbent, 2008, 167) making their goal of a different constitutional status less attainable.

In the wake of this period, politicians were forced to address urban concerns through extra-constitutional means. Upon his election in 1993, Prime Minister Jean Chrétien launched a series of infrastructure renewal projects that sought to appease local governments as such projects have a direct impact on the areas these governments represent. By appeasing city autonomy and authority movements through its spending power, the federal government was able to work with municipalities without provincial mediation. Such is the current strategy of Stephen Harper's "open federalism," a policy that respects provincial jurisdiction, but operates within municipal frameworks through the federal government's constitutional spending power. This approach to federalmunicipal relations has even been referred to as "agenda by stealth."

Perhaps the best example of the federal response to both the city autonomy and city authority movements is that of Paul Martin's Liberal government (2004-2006). Using both formal institutions of government and informal cooperative governance, Martin sought to address Canadian policy with an "urban lens." The former was established through the creation of the Ministry of State for Infrastructure and Communities and the Parliamentary Secretariat responsible for cities; the latter was implemented through the creation of advisory committees, GST rebates, and similar tax cuts like the Gas Tax Transfer. In this way, Martin's approach to municipal demands was based on processes of both government and governance; however, his notion of an "urban lens" favours urban authority movements as cities were granted no more power than they previously held, but instead better informal (i.e., non-elected) representation in federal affairs. In summary, Martin's policies were created to please urban authority rather than urban autonomy advocates.

Many of these policies have been continued under the Harper government. Like the Martin government, Harper's policies are flexible and negotiable as they deny constitutional change. In this way, these policies exist within the Mushy Middle as they 
are pragmatic, highly dependent on compromise, and heavily reliant on the ideologies of leaders. This view acknowledges that a municipality's autonomy is not only defined by constitutional legislation, but also by the practicalities that exist in its governance. This approach to municipal governance proves effective in the Canadian political system as it acknowledges the limitations put on governments by the Constitution while also making adjustments to policies in response to Canada's increasing urbanization.

Other tri-level agreements exist in light of the near impenetrability of the Constitution. City Charters exist to express the uniqueness of a province's relationship to a particular city. The Greater Toronto Charter (2001) articulates the autonomist Torontonian desire to "form an order of government that is a full partner of the Federal and Provincial Governments of Canada." "6 Other agreements, such as the Stronger City of Toronto for a Stronger Ontario Act (2006), acknowledge the importance of a city to its province and country. Still, other agreements, such as the Vancouver Agreement (2000), facilitate more municipal power through cooperative "partnerships between [all three governmental levels], community organizations and businesses" (Vancouver Agreement, 2009). Each of these methods has become a valid option for both municipal autonomy and authority advocates as all acknowledge how far away and seemingly impossible constitutional change is. These agreements and legislations show an acknowledgement of the increasing importance of Canada's urban areas, particularly its larger CMAs, and that informal governance options are the only effective ways to empower municipalities within the Canadian governmental system.

In conclusion, governmental action in Canada can be seen as being mediated through a global lens that often leaves municipal governments constrained by agreements they are not a part of. As such, "the likelihood that central governments would become more involved in major issues relating to urban growth and development than they have been in the past" (Sancton, 2008, 131) rises as these governments recognize the increasing importance of city-regions to the national economy. In addition, local governments are forced to find ways to act creatively within their own areas of jurisdiction. This has led to different reactions at the local level: Some seek for municipal

\footnotetext{
${ }^{6}$ This is quoted in Sanction, 2008, 17. The original source is: "The Greater Toronto Charter," in Broadbent et al., Towards a New City of Toronto Act, 2005, 40.
} 
autonomy, others for greater municipal authority. The first seeks constitutional change in the formal structures of government while the latter seeks cooperation between orders of governments to best govern within the constitutional confines placed upon them; however, both views seek a level of decentralization of authority to local governments. In this way, to label Canada as an 'urban nation' is to acknowledge the need to decentralize power to a particular point. As this paper has shown, this decentralization gives local governments more authority than autonomy.

While the debate between municipal autonomy and authority will still continue in the years to come, there is no debate about the growing importance of city-regions and the various levels of local governments in Canada. Both autonomy and authority advocates agree that urbanization "is a powerful trend driven by positive attraction, and that no amount of intervention will hold it back" (Broadbent, 2008, 42), and, as such, "cities are becoming increasingly important as sources of innovation and wealth in our society" (Sancton, 2008, 3). As cities continue to be the main areas of population growth, for nearly 90\% of Canada's population growth took place its 33 CMAs in 2006 (Statistics Canada, 2009-01-20), the implications of urbanization will continue to be an important dimension of Canadian politics. As a result, urban autonomy movements will continue to arise, calling for constitutional change and equal representation and powers given to upper levels of government. At the same time, urban authority movements will also arise, and it is in these forums that effective and efficient governing will occur. As evidenced in the "urban lens" of Paul Martin's Liberal government, an acknowledgement of the urbanization of the country is best done through policies of cooperation (i.e., governance) rather than through constitutional change (i.e., government). The mix of formal institutional change and informal cooperation is both successful and realistic; this form of municipal governance occurs in the pragmatic Mushy Middle, and not in the idealized notions of Home Rule and the creation of urban city-states. 


\section{Bibliography}

Broadbent, Alan. Urban Nation: Why We Need to Give Power Back to the Cities to Make Canada Strong. Toronto: Harper Collins Publishers Ltd, 2008.

Broadbent Group, The. Towards a New City of Toronto Act. 2005. Web resource [http://www.canadascities.ca/pedf/cityoftorontoact_june2005.pdf].

Grinspun, Ricardo and Yasmine Shamsie. 'Canada, Free Trade, and 'Deep Integration' in North America: Context, Problems, and Challenges", Whose Canada?: Continental Integration, Fortress North America and the Corporate Agenda. Montréal: McGill-Queen's University Press, 2007. 3-53.

Martin, Seymour Lipset. Continental Divide: The Values and Institutions of the United States and Canada. New York: Routledge, 1990.

Robinson, Ian and Richard Simeon. "The dynamics of Canadian federalism", Canadian Politics, 4 (2004), 119.

Sancton, Andrew. Governing Canada's City Regions: Adapting Form to Function. Edited by France St-Hilaire. Canada: The Institute for Research on Public Policy, 1994.

---. The Limits of Boundaries: Why City-regions Cannot be Self-governing. Montréal: McGill-Queen's University Press, 2008.

Statistics Canada. "Population urban and rural, by province and territory", 2009-09-02. Web resource [http://www40.statcan.gc.ca/101/cst01/demo62a-eng.htm].

Statistics Canada. "Population and Demography", 2009-01-20. Web resource [http://www41.statcan.gc.ca/2008/3867/ceb3867_000-eng.htm].

Stronger City of Toronto for a Stronger Ontario Act. "Bill 53." 2006. Web resource [http://www.toronto.ca/committees/pdf/torontoact.pdf].

Tindal, Richard C. and Susan Nobes Tindal. Local Government in Canada. $7^{\text {th }}$ Edition. Toronto: Nelson Education, 2009.

---. Local Government in Canada. $6^{\text {th }}$ Edition. Toronto: Nelson Education, 2004.

Vancouver Agreement. "The Agreement." 2009. Web resource. [http://www.vancouveragreement.ca/the-agreement/]. 